\title{
Peningkatan Aktivitas dan Hasil Belajar IPA Materi Tubuh Sehat melalui Metode Pembelajaran Jigsaw (Penelitian Tindakan Kelas Peserta Didik Kelas I Semester 1 SDN Ngiyono Tahun Pelajaran 2016/2017)
}

\author{
Mashadi* \\ ${ }^{1}$ SDN Ngiyono, Japah, Blora. Dinas Pendidikan Kabupaten Blora Propinsi \\ Jawa Tengah. Desa Ngiyono Kecamatan Japah Kabupaten Blora 58257, \\ Indonesia \\ *hadimas079@gmail.com
}

\begin{abstract}
The purpose of this study was to improve the activities and learning outcomes of science in class 1 students in the first semester on the Healthy Body material in Ngiyono Public Elementary School through the Jigsaw learning method in the 2016/2017 school year. This type of research is Classroom Action Research conducted in 2 cycles consisting of 2 meetings with 4 stages each cycle, namely planning, implementing actions, observing, and reflecting. The research subjects were class I students, totaling 18 students. Data collection methods used are observation, tests, and documentation. The results of this study are an increase in the activities and learning outcomes of science students in class I. This is shown from the pre cycle average value of activities and student learning outcomes is 70.55 by 7 students. In the first cycle the average value of activities and learning outcomes of students is 78.80 by 11 students while in the second cycle the average value of the results of activities and student learning outcomes is 86.67 by 16 students from 18 students. The activities and learning outcomes of students in science subjects in Healthy Body material in class I in semester 1 increased with the application of the Jigsaw learning method and had fulfilled the indicator of success of $75 \%$.
\end{abstract}

\begin{abstract}
Abstrak. Tujuan penelitian ini adalah untuk meningkatkan aktivitas dan hasil belajar IPA peserta didik kelas I semester 1 pada materi Tubuh Sehat di SD Negeri Ngiyono melalui metode pembelajaran Jigsaw tahun pelajaran 2016/2017. Jenis penelitian adalah Penelitian Tindakan Kelas yang dilaksanakan dalam 2 siklus yang terdiri dari 2 pertemuan dengan 4 tahapan setiap siklus yaitu perencanaan, pelaksanaan tindakan, observasi, dan refleksi. Subyek penelitian adalah peserta didik kelas I yang berjumlah 18 peserta didik. Metode pengumpulan data yang digunakan adalah observasi, tes, dan dokumentasi. Hasil penelitian ini adalah peningkatan aktivitas dan hasil belajar IPA peserta didik kelas I . Hal ini ditunjukkan dari pra siklus rata-rata nilai aktivitas dan hasil belajar peserta didik adalah 70,55 oleh 7 peserta didik. Pada siklus I rata-rata nilai aktivitas dan hasil belajar peserta didik adalah 78,80 oleh 11 peserta didik sedangkan pada siklus II rata-rata nilai hasil aktivitas dan hasil belajar peserta didik adalah 86,67 oleh 16 peserta didik dari 18 peserta didik. Aktivitas dan hasil belajar peserta didik pada mata pelajaran IPA materi Tubuh Sehat di kelas I semester 1 meningkat dengan penerapan metode pembelajaran Jigsaw dan telah memenuhi indikator keberhasilan yaitu sebesar $75 \%$.
\end{abstract}

Kata kunci: metode Pembelajaran Jigsaw, aktivitas belajar, hasil belajar IPA, materi Tubuh Sehat 


\section{Pendahuluan}

Pendidikan memiliki peran yang sangat penting untuk setiap kehidupan individu. Pendidikan merupakan suatu hal dasar yang harus ada dalam setiap diri individu. Pendidikan akan memberikan pengaruh yang besar untuk bangsa ini. Dalam mengembangkan pengetahuan maupun pemahaman peserta didik diperlukan suatu metode yang menarik rasa ingin tahu peserta didik. Pada pembelajaran Ilmu Pengetahuan Alam peserta didik belajar tentang alam. Mereka akan belajar untuk hanya tentang teori tetapi juga tentang cara berinteraksi dengan alam, bagaimana cara merawat dan menjaga alam, dan apa itu alam. Dengan menggali rasa ingin tahu pada peserta didik maka bukan hanya prestasi belajar peserta didik yang meningkat tetapi juga pemahaman peserta didik tentang pembelajaran tersebutlah yang akan mengalami peningkatan.

Pembelajaran Ilmu Pengetahuan Alam bukanlah teori yang harus dibaca dan dihafalkan oleh peserta didik tetapi suatu pembelajaran yang mendekatkan peserta didik dengan alam sekitarnya. Ilmu Pengetahuan Alam (IPA) merupakan suatu pengetahuan yang tersusun terbimbing dan sistematis. Hal ini sejalan dengan kurikulum KTSP (Depdiknas, 2006) bahwa "IPA berhubungan dengan cara mencari tahu tentang alam secara sistematis, sehingga bukan hanya penguasaan kumpulan pengetahuan yang berupa fakta, konsep, atau prinsip saja tetapi juga merupakan suatu proses penemuan". Ilmu Pengetahuan Alam merupakan "usaha manusia dalam memahami alam semesta melalui pengamatan yang tepat pada sasaran, serta menggunakan prosedur yang benar, dan dijelaskan dengan penalaran yang valid sehingga dihasilkan kesimpulan yang betul" [1].

Mereka mampu memahami dan merasakan alam sekitar, sehingga nantinya para peserta didik dapat bertanggung jawab terhadap alam sekitar mereka. Dengan metode pembelajaran yang baik akan membuat peserta didik selalu ingin tahu dan mempelajari apa yang ada di alam sekitarnya. Sehingga akan meningkatkan hasil belajara peserta didik. Hasil belajar adalah hasil yang diperoleh seseorang peserta didik untuk mengetahui sejauh mana bahan pelajaran atau materi yang diajarkan yang sudah diterima oleh peserta didik [2]. Hasil belajar merupakan hasil dari suatu interaksi tindak belajar dan tindak mengajar [3]. Dari sisi guru tindak mengajar diakhiri dengan proses evaluasi hasil belajar. Dari sisi peserta didik hasil belajar merupakan berakhirnya puncak proses belajar.

Tetapi kenyataan di lapangan banyak sekali hal yang bertolak belakang dengan apa yang telah dipaparkan penulis. Berdasarkan hasil observasi pra siklus peserta didik kelas I SD Negeri Ngiyono pada pembelajaran IPA diperoleh aktivitas dan hasil belajar IPA peserta didik yang masih rendah. Salah satu metode pembelajaran yang sesuai dan menarik bagi peserta didik adalah metode pembelajaran Jigsaw. Metode pembelajaran Jigsaw adalah sebuah tehnik pembelajaran kooperatif dimana peserta didik, bukan guru, yang memiliki tanggung jawab lebih besar dalam pelaksanaan pembelajaran. Model pembelajaran kooperatif tipe jigsaw merupakan model pembelajaran kooperatif, dengan peserta didik belajar dalam kelompok kecil yang terdiri dari 4-6 orang secara heterogen dan bekerjasama saling ketergantungan yang positif dan bertanggung jawab atas ketuntasan bagian materi pelajaran yang harus dipelajari dan menyampaikan materi tersebut kepada kelompok yang lain.Teori yeng melandasi pembelajaran kooperatif jigsaw adalah teori konstruktivisme. Pada dasarnya pendekatan teori konstruktifisme dalam belajar adalah suatu pendekatan di mana peserta didik secara individu menemukan dan mentranseformasikan imformasi yang kompleks, memeriksa informasi dengan aturan yang dan merivisinya bila perlu [1]. Adapun tujuan dari model pembelajaran jigsaw ini adalah untuk mengembangkan kerja tim, ketrampilan belajar kooperatif, dan menguasai pengetahuan secara mendalam yang tidak mungkin diperoleh bila mereka mencoba untuk mempelajari semua materi sendirian.

Berorientasi dari latar belakang di atas maka dapat dirumuskan permasalahan yaitu Apakah penerapan metode pembelajaran Jigsaw dapat meningkatkan aktivitas dan hasil belajar peserta didik pada mata pelajaran IPA materi Tubuh Sehat peserta didik kelas I di SD Negeri Ngiyono pada tahun pelajaran 2016/2017?" Tujuan dari penelitian ini adalah Untuk mengetahui penerapan metode pembelajaran Jigsaw terhadap peningkatan aktivitas dan hasil belajar IPA peserta didik kelas I pada materi Tubuh Sehat di SD Negeri Ngiyono. 


\section{Metode}

Jenis penelitian yang digunakan adalah penelitian kualitatif. Menurut Rubiyanto (2011: 47) penelitian kualitatif merupakan suatu penelitian yang menghasilkan data deskriptif (katakata tertulis/lisan dari orang-orang yang diamati) dan digunakan untuk meneliti kondisi alamiah. Penelitian kualitatif ini menggunakan desain Penelitian Tindakan Kelas (PTK). Penelitian tindakan kelas adalah suatu bentuk pencermatan dari kegiatan pembelajaran yang dilakukan di dalam kelas untuk meningkatkan suatu hal di mana guru telah menentukan fokus permasalahan, tindakan yang harus dilakukan, dan menentukan tingkat keberhasilan dari tindakan tersebut [4]. Penelitian Tindakan Kelas (PTK) dilaksanakan dalam beberapa siklus dan setiap siklus terdiri dari empat tahapan yaitu perencanaan (planning), pelaksanaan tindakan (action), pengamatan (observation), dan refleksi (reflection). Subjek penelitian dibagi menjadi dua, sebagai berikut : subjek pelaku tindakan yaitu guru sebagai peneliti dan subjek penerima tindakan adalah peserta didik kelas I SD Negeri Ngiyono Tahun Pelajaran 2016/2017 dengan jumlah peserta didik 18 yang terdiri dari 9 peserta didik laki-laki dan 9 peserta didik perempuan.

\section{Hasil Pembahasan}

Hasil penilaian aktivitas dan hasil belajar peserta didik yang dilakukan sebelum pelaksanaan siklus (pra siklus) pada pembelajaran IPA kelas I materi Tubuh Sehat diketahui bahwa persentase ketuntasan baru sekitar $40,00 \%$ atau hanya 7 peserta didik saja yang tuntas dari 18 peserta didik di kelas I SD Negeri Ngiyono. Dan rata-rata nilai aktivitas dan hasil belajar IPA peserta didik sebelum tindakan adalah 70,55. Untuk lebih jelasnya dapat dilihat pada tabel di bawah.

Tabel 1. Hasil belajar IPA peserta didik kelas I materi Tubuh Sehat Pra siklus

\begin{tabular}{ccccl}
\hline NO & NAMA & KKM & NILAI & KETERANGAN \\
\hline 1 & A & 75 & 60 & Belum Tuntas \\
2 & B & 75 & 50 & Belum Tuntas \\
3 & C & 75 & 80 & Tuntas \\
4 & D & 75 & 70 & Belum Tuntas \\
5 & E & 75 & 80 & Tuntas \\
6 & F & 75 & 70 & Belum Tuntas \\
7 & G & 75 & 90 & Tuntas \\
8 & H & 75 & 60 & Belum Tuntas \\
9 & I & 75 & 50 & Belum Tuntas \\
10 & J & 75 & 50 & Belum Tuntas \\
11 & K & 75 & 100 & Tuntas \\
12 & L & 75 & 70 & Belum Tuntas \\
13 & M & 75 & 60 & Belum Tuntas \\
14 & N & 75 & 80 & Tuntas \\
15 & O & 75 & 70 & Belum Tuntas \\
16 & P & 75 & 70 & Belum Tuntas \\
17 & Q & 75 & 80 & Tuntas \\
18 & R & 75 & 80 & Tuntas \\
& JUMLAH & & 1270 & \\
& RATA-RATA & 70,55 & \\
& KETUNTASAN KLASIKAL & & $40,00 \%$ & \\
\hline
\end{tabular}

Berdasarkan tabel di atas maka dapat digambarkan ke dalam grafik seperti di bawah ini : 


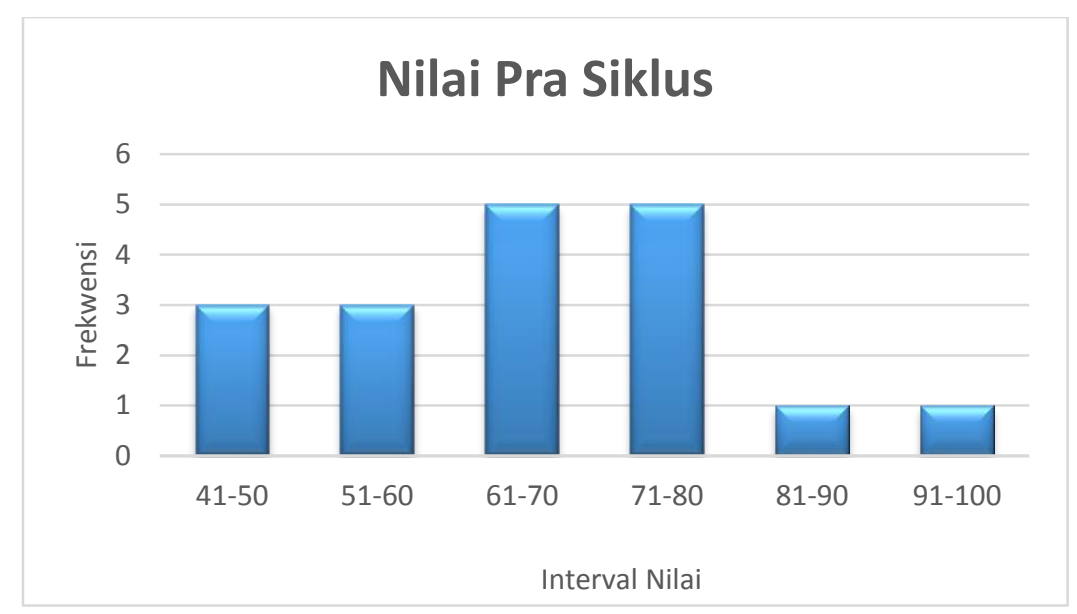

Gambar 1. Grafik Frekuensi Hasil Belajar IPA Peserta didik Kelas I Materi Tubuh Sehat Sebelum Tindakan (Pra Siklus)

Hasil analisis dan hasil observasi siklus I diperoleh persentase ketuntasan aktivitas dan hasil belajar kelas I pada pembelajaran IPA materi Tubuh Sehat adalah 64,00\% atau hanya 11 peserta didik yang mencapai nilai ketuntasan. Dan rata-rata nilai aktivitas dan hasil belajar kelas I pada pembelajaran IPA materi Tubuh Sehat pada kegiatan siklus I adalah 78,80. Dan terjadi peningkatan aktivitas dan hasil belajar peserta didik kelas I pada pembelajaran IPA materi Tubuh Sehat dari pra siklus ke siklus I sebesar $24,00 \%$.

Tabel 2. Hasil Belajar IPA Peserta didik Kelas I Materi Tubuh Sehat siklus I

\begin{tabular}{ccccl}
\hline NO & NAMA & KKM & NILAI & KETERANGAN \\
\hline 1 & A & 75 & 60 & Belum Tuntas \\
2 & B & 75 & 60 & Belum Tuntas \\
3 & C & 75 & 90 & Tuntas \\
4 & D & 75 & 80 & Tuntas \\
5 & E & 75 & 80 & Tuntas \\
6 & F & 75 & 80 & Tuntas \\
7 & G & 75 & 100 & Tuntas \\
8 & H & 75 & 70 & Belum Tuntas \\
9 & I & 75 & 80 & Tuntas \\
10 & J & 75 & 60 & Belum Tuntas \\
11 & K & 75 & 100 & Tuntas \\
12 & L & 75 & 80 & Tuntas \\
13 & M & 75 & 70 & Belum Tuntas \\
14 & N & 75 & 100 & Tuntas \\
15 & O & 75 & 80 & Tuntas \\
16 & P & 75 & 70 & Belum Tuntas \\
17 & Q & 75 & 90 & Tuntas \\
18 & R & 75 & 70 & Belum Tuntas \\
& JUMLAH & & 1420 & \\
& RATA-RATA & & 78,80 & \\
& KETUNTASAN KLASIKAL & & $64,00 \%$ & \\
\hline
\end{tabular}


Berdasarkan tabel di atas maka dapat digambarkan ke dalam grafik seperti di bawah ini :

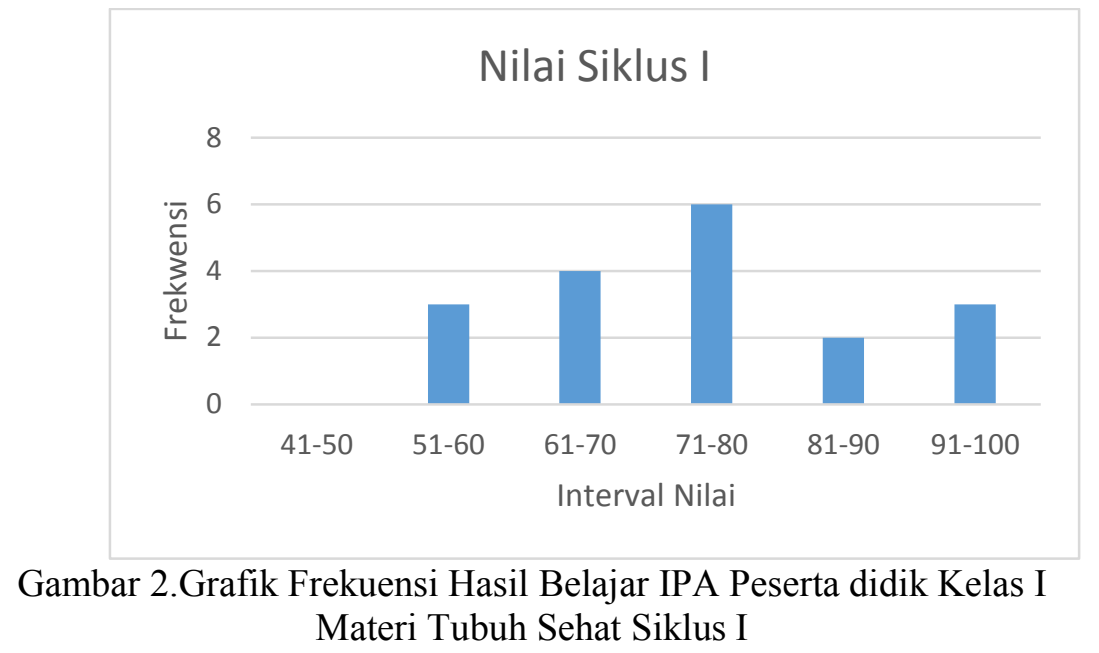

Dari hasil analisis dan hasil observasi siklus II diperoleh persentase ketuntasan aktivitas dan hasil belajar kelas I pada pembelajaran IPA materi Tubuh Sehat adalah 92,00\% atau hanya 16 peserta didik yang mencapai nilai ketuntasan. Dan rata-rata nilai aktivitas dan hasil belajar kelas I pada pembelajaran IPA materi Tubuh Sehat pada kegiatan siklus II adalah 86,67. Dan terjadi peningkatan aktivitas dan hasil belajar peserta didik kelas I pada pembelajaran IPA materi Tubuh Sehat dari siklus I ke siklus II sebesar 28,00\%.

Tabel 3.Hasil Belajar IPA Peserta didik Kelas I Materi Tubuh Sehat Siklus II

\begin{tabular}{ccccl}
\hline NO & NAMA & KKM & NILAI & KETERANGAN \\
\hline 1 & $\mathrm{~A}$ & 75 & 80 & Tuntas \\
2 & $\mathrm{~B}$ & 75 & 70 & Belum Tuntas \\
3 & $\mathrm{C}$ & 75 & 100 & Tuntas \\
4 & $\mathrm{D}$ & 75 & 90 & Tuntas \\
5 & $\mathrm{E}$ & 75 & 80 & Tuntas \\
6 & $\mathrm{~F}$ & 75 & 90 & Tuntas \\
7 & $\mathrm{G}$ & 75 & 100 & Tuntas \\
8 & $\mathrm{H}$ & 75 & 80 & Tuntas \\
9 & $\mathrm{I}$ & 75 & 90 & Tuntas \\
10 & $\mathrm{~J}$ & 75 & 80 & Tuntas \\
11 & $\mathrm{~K}$ & 75 & 100 & Tuntas \\
12 & $\mathrm{~L}$ & 75 & 80 & Tuntas \\
13 & $\mathrm{M}$ & 75 & 80 & Tuntas \\
14 & $\mathrm{~N}$ & 75 & 100 & Tuntas \\
15 & $\mathrm{O}$ & 75 & 90 & Tuntas \\
16 & $\mathrm{P}$ & 75 & 80 & Tuntas \\
17 & $\mathrm{Q}$ & 75 & 100 & Tuntas \\
18 & $\mathrm{R}$ & 75 & 70 & Belum Tuntas \\
& JUMLAH & & 1660 & \\
& RATA-RATA & & 86,67 & \\
& KETUNTASAN KLASIKAL & & $92,00 \%$ & \\
\hline
\end{tabular}


Berdasarkan tabel di atas maka dapat digambarkan ke dalam grafik seperti di bawah ini :

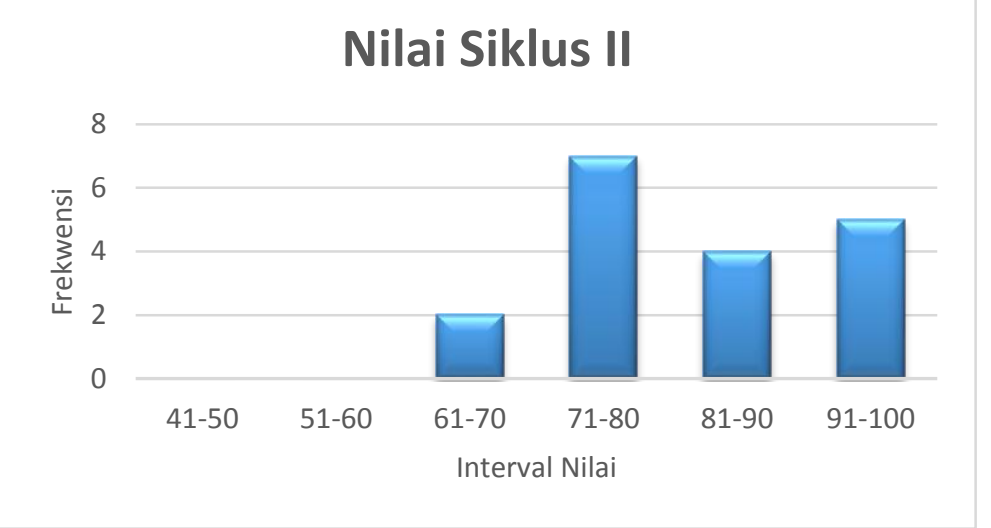

Gambar 3.Grafik Frekuensi Hasil Belajar IPA Peserta didik Kelas I Materi Tubuh Sehat Siklus II

Berdasarkan data dari pra siklus, siklus I, dan siklus II dapat diketahui bahwa setiap siklus mengalami peningkatan. Dan dari data yang diperoleh dari siklus II persentase aktivitas dan hasil belajar peserta didik kelas I pada pembelajaran IPA materi Tubuh Sehat di SD Negeri Ngiyono adalah $92,00 \%$ sudah memenuhi indikator keberhasilan yaitu sebesar $75 \%$. Untuk lebih jelasnya dapat dilihat pada tabel di bawah ini.

Tabel 4.Perbandingan Ketuntasan Pra Siklus, Siklus I Dan Siklus II

\begin{tabular}{lccc}
\hline NILAI & PRA & SIKLUS \\
SIKLUS & SIKLUS 1 & II \\
\hline $41-50$ & 3 & 0 & 0 \\
$51-60$ & 3 & 3 & 0 \\
$61-70$ & 5 & 4 & 2 \\
$71-80$ & 5 & 6 & 7 \\
$81-90$ & 1 & 2 & 4 \\
$91-100$ & 1 & 3 & 5 \\
\hline
\end{tabular}

Berdasarkan tabel 4.di atas maka dapat digambarkan ke dalam grafik seperti di bawah ini :

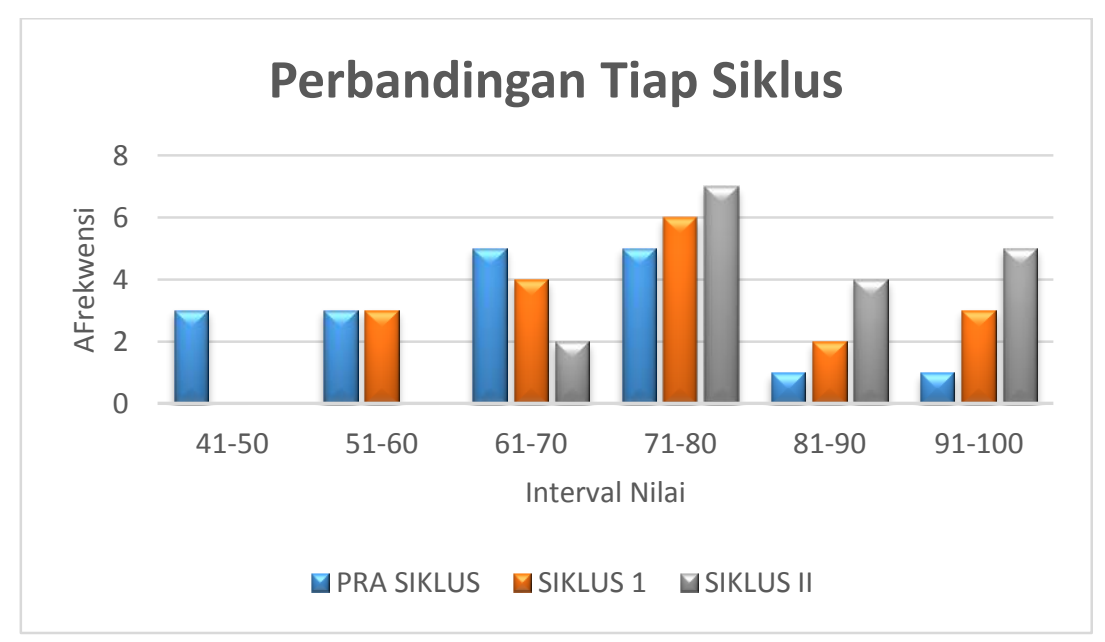

Gambar 4. Grafik Perbandingan Ketuntasan Pra Siklus, Siklus I dan Siklus II 
Dari data yang diperoleh dari pra siklus, siklus I, dan siklus II dapat disimpulkan bahwa terjadi peningkatan aktivitas dan hasil belajar peserta didik kelas I pada pembelajaran IPA materi Tubuh Sehat di SD Negeri Ngiyono tahun pelajaran 2015/2016. Hal ini dikarenakan penggunaan pendekatan metode pembelajaran Jigsaw pada peserta didik kelas I dan ternyata aktivitas dan hasil belajar IPA peserta didik meningkat [5]. Sehingga peserta didik lebih memahami pembelajaran dan pengetahuan peserta didik menjadi lebih luas dan terarah.

\section{Kesimpulan}

Hasil penelitian tindakan kelas yang dilakukan dapat disimpulkan bahwa penerapan pendekatan metode pembelajaran Jigsaw dapat meningkatkan aktivitas dan hasil belajar peserta didik kelas I pada pembelajaran IPA materi Tubuh Sehat di SD Negeri Ngiyono tahun pelajaran 2015/2016. Hal ini dapat dilihat dari indikator keberhasilan yang diamati telah mencapai target yaitu sebesar $92,00 \%$.

\section{Referensi}

[1] Teti, Sobari. 2006 Penerapan Model pembelajaran Koopratif Tipe Jigsaw untuk Meningkatkan Hasil Belajar Siswa. Skipsi. Surakarta: Universitas Negeri Surakarta [2]Arikunto, Suhasimi. 2001. Prosedur Penelitian, Suatu Pendekatan Praktek. Jakarta: Bina Aksara

[3] Dimyati dan Mudjiono. 2006. Belajar dan Pembelajaran. Jakarta : PT Rineke Cipta

[4] Rubiyanto. 2011. Metode Penelitian Pendidikan. Surakarta:PSKGJ FKIP UMS

[5] Arens. 1997. Model-model Pembelajaran Inovatif Berorientasi Konstruktivis. Jakarta : Prestasi Pustaka Publiser 